\title{
Comparison of Salvia officinalis L. essential oil and antifungal agents against candida species
}

\author{
Parisa Badiee ${ }^{1 *}$, Abdol Reza Nasirzadeh ${ }^{2}$ and Mahshid Motaffaf ${ }^{2}$ \\ Correspondence: badieep@gmail.com \\ ${ }^{1}$ Professor Alborzi Clinical Microbiology Research Center, Shiraz University of Medical Sciences, Shiraz, Iran. \\ ${ }^{2}$ Beasat Research Center, Agricultural Faculty, Shiraz University, Shiraz, Iran.
}

\begin{abstract}
Background: Systemic fungal infections due to pathogenic yeasts are increasing in high-risk patients, and a need is emerging for novel antifungal agents with potent inhibitory activity toward a wide range of pathogenic fungi. In this study we investigated the composition and antifungal activity of the essential oil of Salvia officinalis (Lamiaceae) against standard species of Candida and compared the results with commercial antifungal agents.

Methods: The aerial parts of Saliva officinalis were collected in May 2011. The essential oil was extracted and analyzed by gas chromatography-mass spectrometry. The susceptibility profiles of different Candida species were determined by micro broth dilution assays with oil extracts and a panel of antifungal agents.

Results: The minimum inhibitory concentrations of essential oil extracts against C. albicans, C. parapsilosis, C. krusei (standard species), C. albicans and C. glabrata (isolated from patients) were 15.6, 3.9, 31.3, 31.3 and $1.9 \mu \mathrm{g} / \mathrm{ml}$, respectively. Chemical analysis of the essential oil revealed the presence of 40 components that made up $99.58 \%$ of the total composition. Cineole, borneol, $\alpha$-thujone, ledene, $\beta$-pinene, $\alpha$-humulene and trans-caryophyllene were the major components of the oil. Conclusion: The oil extract of Salvia officinalis showed good antifungal activity, and could serve as a natural alternative to synthetic fungicides for the control of some important fungal diseases.
\end{abstract}

Keywords: Antifungal activity, Candida albicans, Cineole, Candida glabrata

\section{Background}

Salvia (S) officinalis L., a member of the Lamiaceae family popularly known as salvia or sage, is an aromatic plant widely distributed in the world. Common sage, since ancient times, has been an ingredient in perfumes, a flavoring in a variety of food preparations, and a medicinal plant used in the healthy Mediterranean diet. Hence its name, Salvia, which derives from the Latin meaning "to heal" [1-3].

The increase in nosocomial systemicfungal infections due to pathogenic yeast has led researchers to seek novel antifungal agents with potent inhibitory activity toward a wide range of pathogenic fungi and low side effects for patients. Essential oil (EO) extracted from S. officinalis is used in the treatment of a large range of diseases such as respiratory and digestive syndromes, heart and blood circulation, metabolic and endocrine diseases, as well as for its many other therapeutic effects $[4,5]$. Many properties have been reported for this plant, including its antibacterial activity against gram-positive cocci and bacilli such as Staphyloccocu saureus and Bacillus subtilis, and against gram-negative bacilli such as Escherichia coli. The EO also has cytotoxic activity against Vero cells and antiviral activity against HIV, Herpes simplex virus 1 and vesicular stomatitis virus [6-8], anti-angiogenic and antitumor effects [9], and antioxidant activity due to osmarinic acid, carnosic acid and phenolic components [10-13]. Recent studies have identified diterpenoids, triterpenoids, flavonoids and phenolic glycosides isolated from the plant [14-16].

In this study, we investigated the composition and antifungal activity of $S$. officinalis EO extracted from the flowers and leaves against standard species of Candida (C.) albicans (a frequent pathogenic species), Candida glabrata (one of the most resistant fungi to routine antifungal agents $[17,18])$, Candida krusei and Candida parapsilosis. We compared this activity with polyene and azole antifungal agents in broth microdilution assays.

\section{Methods}

The aerial parts of S. officinalis L. were collected from the pharmacological plant garden of Isfahan University of Medical Sciencesin Isfahan, central Iran, in May 2011.

C 2012 Badiee et al; licensee Herbert Publications Ltd. This is an open access article distributed under the terms of Creative Commons Attribution License (http://creativecommons.org/licenses/by/3.0),This permits unrestricted use, distribution, and reproduction in any medium, provided the original work is properly cited. 
Vouchers were deposited in the herbarium of the Faculty of Science and identified by one of the authors (ARN). The leaves and flowers were harvested and cleaned in a shaded, well-aired place for 15 days. Fifty grams of the dried plant material was cut into small pieces and place in $500 \mathrm{ml}$ distilled water for 2.5 hours at $100^{\circ} \mathrm{C}$ after boiling at $290^{\circ} \mathrm{C}$ with a clevenger apparatus [19]. The oils were obtained with n-pentane as a collecting solvent, and were dried over anhydrous sodium sulfate (Fluka, Steinheim, Germany). The EO was extracted at a yield of $4 \%$ per $50 \mathrm{~g}$ dried plant material, and was stored in amber vials at $4^{\circ} \mathrm{C}$ until analysis.

A dilution of the $\mathrm{EO}$ in hexane $(10 \mathrm{mg} / \mathrm{ml})$ was analyzed by gas chromatography-FID (Agilent Technologies 7890A, Turin, Italy) with a $30 \mathrm{~m} \times 0.32 \mathrm{~mm}$ capillary column, a film thickness of $0.25 \mu \mathrm{m}$ and injector temperature of $280^{\circ} \mathrm{C}$ with nitrogen as the carrier gas. Mass spectrophotometry was performed (Agilent 5975C) under the following conditions: $30 \mathrm{~m}$ capillary column, film thickness $0.25 \mu \mathrm{m}$, temperature program $60^{\circ} \mathrm{C}$ for $5 \mathrm{~min}$, then heating to $210^{\circ} \mathrm{C}$ at a rate of $3^{\circ} \mathrm{C} / \mathrm{min}$, injector temperature $280^{\circ} \mathrm{C}$, with helium as the carrier gas. The constituents were identified by comparison of their mass spectra fragmentation, retention indices, and standard materials with authentic compounds or with data from the literature [20].

As laboratory standard species, we used C. albicans ATCC 90028, C. parapsilosis ATCC 22019 and C. krusei ATCC 6258 along with three species of each $C$. albicans and $C$. glabrata [17] isolated from patients and identified with the API system (bioMerieux, Marcy l'Etoile, France). The susceptibility patterns of the species were determined by microbroth dilution assay tested with $S$. officinalis EO and fluconazole, amphotericin B, ketoconazole (SigmaAldrich Chemie, Steinheim, Germany), itraconazole (Jenssen Pharmaceutical, Beerse, Belgium), posaconazole( Noxafil, Schering-Plough, Kenilworth, NJ, USA), caspofungin (Merck \& Co., Whitehouse Station, NJ, USA) and voriconazole (Pfizer, Tadworth, UK), according to CLSI M27-A2 guidelines [21].

Stock solutions of antifungal agents were prepared in dimethyl sulfoxide or water. Briefly, $100 \mu \mathrm{L}$ RPMI 1640 broth (RPMI, Sigma Chemical Co., St. Louis, MO, USA) buffered to PH 7.0 with $0.165 \mathrm{M}$ morpholine propanesulfonic acid buffer (Sigma) was poured into each well of 96-well plates. In the first column of wells, $100 \mu \mathrm{L}$ of each antifungal agent or EO was added. To dissolve the oil extract in RPMI, $5 \mu \mathrm{L}$ Tween 80 was added and after pipetting 5 times, $100 \mu \mathrm{L}$ of the solution was transferred to the second column. Ten serial two-fold dilutions of the EO and antifungal agents were prepared and evaluated for minimum inhibitory concentration (MIC). The density of the Candida spp. suspensions used as the inoculum was adjusted spectrophotometrically to 0.5 McFarland standard (equivalent to $1-5 \times 10^{6} \mathrm{C} \mathrm{fu} / \mathrm{ml}$ ) and diluted 1:1000 in RPMI 1640 medium (Sigma). Then $100 \mu \mathrm{L}$ of the fungal suspension was added to each well except for negative controls. In each series, the positive control received no antifungal or EO extract, and one negative control with no fungal suspension was also used.

Antifungal activity was seen at 30 to $0.064 \mathrm{mg} / \mathrm{ml}$ for aqueous EO, at final concentrations from 8 to $0.016 \mu \mathrm{g} / \mathrm{ml}$ for amphotericin B, concentrations from 16 to $0.032 \mu \mathrm{g} / \mathrm{ml}$ for itraconazole, ketoconazole, voriconazole, posaconazole and caspofungin, and concentrations from 128 to $0.250 \mu \mathrm{g} /$ $\mathrm{ml}$ for fluconazole. The plates were incubated at $35^{\circ} \mathrm{C}$ for 24 and $48 \mathrm{~h}$. The MIC for amphotericin B and EO was defined as the lowest drug concentration that zone determined the point of complete inhibition (100\%), and for itraconazole, fluconazole, voriconazole, ketoconazole, posaconazole and caspofungin the growth should be decreased by $80 \%$, compared with the respective controls after 24 or 48 hours of visual growth. The results are reported as the mean values of the data recorded in three different experiments.

\section{Results}

The EO was effective against Candida spp. and inhibited the growth of all fungi tested in a dose-dependent manner, at a concentration comparable to that of some other antifungal agents. The MIC of the EO extract was $15.6 \mu \mathrm{g} / \mathrm{ml}$ against C. albicans, $3.9 \mu \mathrm{g} / \mathrm{ml}$ against C. parapsilosis, $31.3 \mu \mathrm{g} / \mathrm{ml}$ against $C$. krusei (standard species), $31.3 \mu \mathrm{g} / \mathrm{ml}$ against $C$. albicans, and $1.9 \mu \mathrm{g} / \mathrm{ml}$ against C. glabrata (isolated from the patients). Because we compared the EO activity with that of antifungal agents, we report our results in $\mu \mathrm{g} / \mathrm{ml}$ rather than $\mathrm{mg} / \mathrm{ml}$, as in similar studies. The MIC of the EO and other antifungal agents are shown in Table 1.

Chemical analysis of the EO revealed the presence of 40 components making up to $99.58 \%$ of the total material (Table 2). The major components were cineole (13.69\%), borneol (13.77\%), a-thujone (12.46\%), ledene (11.05\%), $\beta$-pinene (7.00\%), a-humulene (6.92\%), trans-caryophyllene $(5.28 \%), \beta$-thujone $(4.56 \%)$, camphor $(3.58 \%)$ and naphthalene (3.27\%). Oxygen-containing monoterpenes including cineole, borneol, camphor, a-thujone and ledene predominated.

\section{Discussion}

The species of fungus used in this study were chosen primarily on the basis of their pathogenicity and susceptibility to antifungal agents. The standard species were used in this study because of the sufficient knowledge about the susceptibility pattern of these fungi and C. albicans, and C. glabrata are, the routine pathogenic fungi isolated from the patients. Resistance to antifungal agents such as fluconazole and itraconazole in some species of fungi involved in human infection including C. glabrata and C. krusei has reportedly increased in recent years [22-24]. At the same time, interest has grown in the possible use of natural medicinal plants and plant products as alternatives to inhibit fungal growth.

Our data show that the MIC for all species treated with EO was lower than in other reports, and the EO extracts exhibited substantial antifungal activity against C. glabrata, 
Table 1. Minimum inhibitory concentrations of Salvia officinalis L. essential oil and known antifungal agents after 24 hours.

\begin{tabular}{lllllllll}
\hline Candida species & $\begin{array}{l}\text { Essential } \\
\text { oil } \\
(\mu \mathrm{g} / \mathrm{ml})\end{array}$ & $\begin{array}{l}\text { Amphoeri- } \\
\text { cin B } \\
(\mu \mathrm{g} / \mathrm{ml})\end{array}$ & $\begin{array}{l}\text { Itraconzole } \\
(\mu \mathrm{g} / \mathrm{ml})\end{array}$ & $\begin{array}{l}\text { Flucon- } \\
\mathbf{a z o l e} \\
(\mu \mathrm{g} / \mathrm{ml})\end{array}$ & $\begin{array}{l}\text { Voricon- } \\
\text { azole } \\
(\mu \mathrm{g} / \mathrm{ml})\end{array}$ & $\begin{array}{l}\text { Ketocon- } \\
\text { azole } \\
(\mu \mathrm{g} / \mathrm{ml})\end{array}$ & $\begin{array}{l}\text { Posacon- } \\
\text { azole } \\
(\mu \mathrm{g} / \mathrm{ml})\end{array}$ & $\begin{array}{l}\text { Caspo- } \\
\text { fungin } \\
(\mu \mathrm{g} / \mathrm{ml})\end{array}$ \\
\hline C. albicans & 31.3 & 0.38 & 0.004 & 1.5 & 0.023 & 0.016 & 0.125 & 0.094 \\
C. glabrata & 1.9 & 0.064 & 3.0 & 64 & 0.125 & 1.0 & 2.0 & 0.064 \\
C. albicans & 15.6 & 0.50 & 0.064 & 2.0 & 0.032 & 0.016 & 0.032 & 0.064 \\
C. parapsilosis $^{*}$ & 3.9 & 0.25 & 0.032 & 1.0 & 0.032 & 0.032 & 0.032 & 0.064 \\
${\text { C. } \text { krusei }^{*}}^{3}$ & 31.3 & 0.5 & 0.5 & 16 & 0.25 & 0.5 & 0.250 & 0.032 \\
\hline
\end{tabular}

* Standard species

Table 2. Chemical composition of the essential oil of Salvia officinalis aerial parts.

\begin{tabular}{|c|c|c|c|}
\hline No & Compound & $\begin{array}{l}\text { Percent of } \\
\text { compound }\end{array}$ & $\begin{array}{l}\text { Retention } \\
\text { indices }\end{array}$ \\
\hline 1 & Borneol & 13.77 & 13.896 \\
\hline 2 & Cineole & 13.69 & 8.717 \\
\hline 3 & Alpha.-Thujone & 12.46 & 11.487 \\
\hline 4 & Ledene & 11.05 & 31.239 \\
\hline 5 & Beta-Pinene & 7.00 & 6.966 \\
\hline 6 & Alpha.-Humulene & 6.92 & 25.803 \\
\hline 7 & Trans-Caryophyllene & 5.28 & 24.413 \\
\hline 8 & Beta-Thujone & 4.56 & 11.864 \\
\hline 9 & Alpha-Pinene & 3.89 & 5.771 \\
\hline 10 & Camphor & 3.58 & 12.946 \\
\hline 11 & Naphthalene & 3.27 & 46.877 \\
\hline 12 & Camphene & 2.86 & 6.165 \\
\hline 13 & Bicyclo & 1.75 & 18.839 \\
\hline 14 & Limonene & 0.94 & 8.586 \\
\hline 15 & Caryophyllene oxide & 0.84 & 30.821 \\
\hline 16 & Beta.-Myrcene & 0.69 & 7.310 \\
\hline 17 & Alpha Terpineol & 0.64 & 14.823 \\
\hline 18 & Gamma.-Terpinene & 0.63 & 9.616 \\
\hline 19 & Oxabicyclo & 0.47 & 31.817 \\
\hline 20 & Cyclohexen & 0.37 & 14.279 \\
\hline 21 & Alpha-Thujene & 0.33 & 5.570 \\
\hline 22 & Dimethy & 0.33 & 32.807 \\
\hline 23 & Alpha.-Terpinene & 0.32 & 8.157 \\
\hline 24 & Alpha-Terpinolene & 0.32 & 10.714 \\
\hline 25 & Linalool & 0.32 & 11.224 \\
\hline 26 & Delta.-Cadinene & 0.27 & 28.538 \\
\hline 27 & Sabinene & 0.25 & 6.835 \\
\hline 28 & Bicyclo & 0.25 & 9.919 \\
\hline 29 & Cyclohexadiene & 0.24 & 12.751 \\
\hline 30 & Aromadendrene & 0.22 & 25.162 \\
\hline 31 & H-Cycloprop & 0.22 & 26.043 \\
\hline 32 & H-Cycloprop & 0.22 & 30.615 \\
\hline 33 & cis-Ocimene & 0.21 & 8.849 \\
\hline 34 & Benzene & 0.19 & 8.425 \\
\hline 35 & Isoaromadendrene epoxide & 0.18 & 32.664 \\
\hline 36 & Naphthalenemethanol & 0.18 & 33.310 \\
\hline 37 & Bicyclo & 0.17 & 11.126 \\
\hline 38 & Alpha.-Amorphene & 0.17 & 26.690 \\
\hline 39 & Phenanthrene & 0.15 & 42.288 \\
\hline 40 & Isoaromadendrene epoxide & 0.14 & 34.077 \\
\hline
\end{tabular}

which is highly resistantto itraconazole and fluconazole, two routine antifungal agents used in clinical practice, and posaconazole, a new antifungal agent $[17,18]$. According to Table 1, the MIC of the S. officinalis EO extract was lower for C. glabrata than for other fungi. The EO obtained from anise seeds (Pimpinellaanisu mL.,Apiaceae) showed antimycotic activity against some pathogenic Candida species, but no activity against $C$. glabrata [25]. Earlier research showed that the antifungal activity of any agent depends on the species of fungus and on the plant species. Salvia dominica and $S$. officinalis inhibited the growth of $C$. albicans, but Salvia spinosa showed no activity against this yeast [26]. The EO of other Salvia species was previously shown to have antifungal activity against various Candida species $[\mathbf{2 7}, \mathbf{2 8}]$. In one report from Turkey, the MIC ranged from 3.12 to $25 \mathrm{mg} / \mathrm{ml}$ and as the authors reported " all the extracts exhibited a strong antifungal effect against the fungal cultures" [30]. Bioassays with the EO of Salvia lachnocalyx showed significant inhibition against fungi, with an MIC in the range of $5-10 \mathrm{mg} / \mathrm{ml}$ [31].

In the present study, the lower MIC for S. officinalis EO maybe related to regional variations in the composition of this species. Chemically, EO are primarily composed of mono- and sesquiterpenes and aromatic polypropanoids $[30,31]$ with different amounts and types of oxygenated monoterpene components such as a-thujone, 1,8-cineol, camphor, borneol and bornyl acetate or sesquiterpene components, humulene, viridiflorol and manool $[14,28,32]$. The antifungal activities of sesquiterpenoid constituents were superior to those of monoterpenoid constituents. Among active sesquiterpenoids, T-murolol and a-cadinol possess the greatest activity against plant pathogenic fungi. Limonene and $\beta$-myrcene also showed weak antifungal activity [33]. The major components of Salvia species growing in Turkey are $\alpha$-pinene, $\beta$-pinene, $\beta$-thujone, camphor, carvacrol, lynalyl acetate, sabinyl acetate and cineole [28]. The main differences between the compositions of the EO of sage from Turkey and the sage used in the present study were in the proportions of a-pinene, limonene, linalool and especially viridiflorol, humulene, manool, which were lower in our material.

Drinking sage (S.officinalis) tea could have a hepatotoxicity effect due to free radical formation of $\mathrm{CCl}_{4}[34]$ and 
considering the toxicity of some components like thujone as reported [35]. However, there are some studies, which have not reported any level of hepatotoxicity [36]. Therefore, further studies are neededto make the findings more definitive.

\section{Conclusions}

Our results support the antifungal activityof the EO extract of S. officinalisL. against pathogenic Candida species. More investigations of the antifungal elements of EO and purification of these products will contribute to the development of new natural antifungal drugs for resistant strains of fungi, which could replace currently available synthetic agents.

\section{List of abbreviations \\ S: Salvia \\ EO: essential oil \\ MIC: minimum inhibitory concentration}

\section{Competing interests}

The authors report no competing

interests related to this study.

\section{Authors' contributions}

PB conceived and designed the study, participated in the analysis and interpretation of the data and drafted the manuscript. ARN identified the plant species and performed gas chromatography-mass spectrometry analyses. MM extracted the essential oils. All authors read and approved the final manuscript.

\section{Acknowledgements and funding}

Our sincere thanks go to Dr. Hassan Khajehei for copyediting the manuscript and to K. Shashok (Author AID in the Eastern Mediterranean) for improving the use of English in the manuscript. This work was supported by Professor Alborzi Clinical Microbiology Research Center, Shiraz University of Medical Sciences, Shiraz, Iran.

\section{Publication history}

Received: 08-Aug-2012 Revised: 17-Sep-2012

Re-Revised:24-Sep-2012 Accepted: 08-Oct-2012

Published: 22-Oct-2012

\section{References}

1. Malamas M, Marselos M: The tradition of medicinal plants in Zagori, Epirus (northwestern Greece). J Ethnopharmacol 1992, 37:197-203. | Article | PubMed

2. Kasimu R, Tanaka K, Tezuka Y, Gong ZN, Li JX, Basnet P, Namba T, Kadota $S$ : Comparative study of seventeen Salvia plants: aldose reductase inhibitory activity of water and $\mathrm{MeOH}$ extracts and liquid chromatography-mass spectrometry (LC-MS) analysis of water extracts. Chem Pharm Bull (Tokyo) 1998, 46:500-504. I Article I PubMed

3. Lian-Niang Li: Biologically active components from traditional Chinese medicines. Pure App/Chem, 1998, 70:547-554. I Article

4. Istudor V (2001) Farmacognozie fitochimie fitoterapie. Medicala, Bucuresti2: 2, 13, 60. | Article | PubMed Abstract | PubMed Full Text

5. Lima CF, Valentao PC, Andrade PB, Seabra RM, Fernandes-Ferreira M, Pereira-Wilson C: Water and methanolic extracts of Salvia officinalis protect HepG2 cells from t-BHP induced oxidative damage. Chem Biol Interact 2007, 167:107-115. I Article I PubMed

6. Geuenich S, Goffinet C, Venzke S, Nolkemper S, Baumann I, Plinkert P, Reichling J, Keppler OT: Aqueous extracts from peppermint, sage and lemon balm leaves display potent anti-HIV-1 activity by increasing the virion density. Retrovirology 2008, 5:27. | Article | PubMed Abstract | PubMed Full Text

7. Sivropoulou A, Nikolaou C, Papanikolaou E, Kokkini S, Lanaras T: Antimicrobial, cytotoxic and antiviral activities of Salvia fructicosa essential oil. J Agric Food Chem 1997, 45:3197-3201. | Article

8. Tada M, Okuno K, Chiba K, Ohnishi E, Yoshii T: Antiviral diterpenes from Salvia officinalis. Phytochemistry 1994, 35:539-541. | Article

9. Keshavarz M, Bidmeshkipour A, Mostafaie A, Mansouri K, Mohammadi-Motlagh HR: Anti tumor activity of Salvia officinalis is due to its anti-angiogenic, anti-migratory and anti-proliferative effects. J Cell [yakhteh] 2011, 12:477-482. I Pdf

10. Nakatani N: Chemistry of antioxidants from labiatae herbs. Phytochemicals for cancer prevention. ACS Sympos Ser. Volume 547. Edited by Chi-Tang Ho, Toshihiko Osawa, Mou-Tuan Huang, and Robert T. Rosen: Chapter 16, pp 144-153. I Book

11. Lu Y, Foo LY: Polyphenolics of Salvia--a review. Phytochemistry 2002, 59:117-140. | Article | PubMed

12. Cuvelier ME, Richard $\mathrm{H}$, Berset $\mathrm{C}$ : Antioxidative activity and phenolic composition of pilot-plant and commercial extracts of sage and rosemary. J Am Oil Chem Soc 1996, 73: 645-652. I Article

13. Wang MF, Li JG, Rangarajan M, Shao Y, Lavoie EJ Huang TC, Ho CT: Antioxidative phenolic compounds from sage (Salvia officinalis). J Agric Food Chem 1998, 46: 4869-4873. I Article

14. Couladis M, Tzakou O, Mimica-Dukić N , Jančić R,Stojanović D: Essential oil of Salvia officinalisL. from Serbia and Montenegro. Flavor and Fragrance J 2002, 17:119-126. | Article

15. Durling NE, Catchpole OJ, Grey JB, Webby RF, Mitchell KA, Foo LY, Perry NB: Extraction of phenolic and essential oil from dried sage (Salvia officinalis) using ethanol-water mixtures. Food Chem 2007, 101:14171424. I Article

16. Langer R, Mechtler $\mathrm{CH}$, Jurenitsc J: Composition of the essential oils of commercial samples of Salvia officinalis L. and S. fruticosa Miller,a comparison of oils obtained by extraction and steam distillation. Phytochem Anal 1998, 7:289-293. | Article

17. Badiee P, Alborzi A: Susceptibility of clinical Candida species isolates to antifungal agents by E-test, Southern Iran: A five year study. Iran J Microbiol 2011, 3:183-188. | Article | PubMed Abstract | PubMed Full Text

18. Horowitz BJ: Mycotic vulvovaginitis: a broad overview. Am J Obstet Gynecol 1991, 165:1188-1192. | Article | PubMed

19. European Pharmacopoeia (2004) 5th ed., Council of Europe, Strasbourg Cedex, France I, 2.8.12:217-218.

20. Adams RP (1995) Identification of essential oil components by gas choromatograph/mass spectroscopy. Carol Stream: Allured Publishing Corporation, 469-485.

21. Reference method for broth dilution antifungal susceptibility testing of yeasts (2002) Approved standard. 2nd ed. NCCLS document M27A2. Wayne, PA: National Committee for Clinical Laboratory Standards. I Article | PubMed Abstract | PubMed Full Text

22. Badiee P, Alborzi A, Shakiba E, Farshad S, Japoni A: Susceptibility of Candida species isolated from immunocompromised patients to antifungal agents. East Mediterr Health J 2011, 17:425-430. I Pdf I PubMed

23. Badiee P, Alborzi A, Davarpanah MA, Shakiba E: Distributions and antifungal susceptibility of Candida species from mucosal sites in HIV positive patients. Arch Iran Med 2010, 13:282-287. I Pdf I PubMed

24. Badiee P, Alborzi A, Shakiba E, Ziyaeyan M, Rasuli M: Molecular identification and in-vitro susceptibility of Candida albicans and Candida dubliniensis isolated from immunocompromised patients. Iranian Red Cres Med J 2009, 11:391-397. I Article

25. Kosalec I, Pepeljnjak S, Kustrak D: Antifungal activity of fluid extract and essential oil from anise fruits (Pimpinella anisum L., Apiaceae). Acta Pharm 2005, 55:377-385. | Article | PubMed 
Badiee et al. Journal of Pharmaceutical Technology \& Drug Research 2012, http://www.hoajonline.com/journals/pdf/2050-120X-1-7.pdf

26. Hassawi $D$, Kharma A: Antimicrobial activity of some medicinal plants against Candida albicans. J BiolSci 2006, 6:109-114. | Article

27. Jirovetz L, Wleek K, Buchbauer G, Gochev V, Girova T: Antifungal activities of essential oils of Salvia lavandulifolia, Salvia officinalis and Salvia sclarea against various pathogenic Candida species. J Essential Oil Bearing Plants 2007, 10:430-439. I Article

28. DulgerB , Hacioglu N: Antifungal activity of endemic Salvia tigrina in Turkey. Trop J Pharmaceut Res 2008, 7:1051-1054. I Pdf

29. Salehi P, Sonboli A, Fathi F (2007) Essential oil composition and antimicrobial activity of Salvia lachnocalyx hedge from Iran. Int. J Essent Oil Ther 1: 45-48.

30. Croteau R (1986) Biochemistry of monoterpenes and sesquiterpenes of the essential oils. Herbs, spices and medicinal plants: Recent advances in botany, horticulture, and pharmacology 1: 81-135.

31. Guenther E (1972) The production of essential oils: methods of distillation, effleurage, maceration, and extraction with volatile solvents. In: Guenther E (ed) The essential oils. History, origin in plants, production analysis 1:85-188.

32. BalchinML, Deans SG, Eaglesham E: Relationship between bioactivity and chemical composition of commercial essential oils. J Flavour Frag 1998, 13:98-104. | Article

33. Kordali S, Cakir A, Zengin H, Duru ME: Antifungal activities of the leaves of three Pistacia species grown in Turkey. Fitoterapia 2003, 74:164-167. | Article | PubMed

34. Lima CF, Fernandes-Ferreira M, Pereira-Wilson C: Drinking of Salvia officinalis tea increases $\mathrm{CCl}(4)$-induced hepatotoxicity in mice. Food Chem Toxicol 2007, 45:456-464. | Article | PubMed

35. Committee on herbal medicinal products, public statement on Salvia officinalis L., Aetheroleum, European Medicines Agency, London, 12 November 2009 .7 Westferry Circus, Canary Wharf, London, E14 4HB, UK.

36. Sa CM, Ramos AA, Azevedo MF, Lima CF, Fernandes-Ferreira M, Pereira-Wilson C: Sage tea drinking improves lipid profile and antioxidant defences in humans. Int J Mol Sci 2009, 10:3937-3950. | Article | PubMed Abstract | PubMed Full Text

Citation:

Badiee P, Nasirzadeh A R and Motaffaf M:

Comparison of Salvia officinalis L. essential oil and antifungal agents against candida species. journal of Pharmaceutical Technology and Drug Research 2012, 1:7.

http://dx.doi.org/10.7243/2050-120X-1-7 